\title{
O Governo João Goulart e o golpe de 1964: memória, história e historiografia*
}

\author{
Lucilia de Almeida Neves Delgado**
}

Análise sobre os diferentes enfoques interpretativos e historiográficos referentes à trajetória política do ex-presidente João Goulart, a crise institucional do início da década de 1960 e o golpe político de 1964. Ênfase especial recai sobre a relação da memória com a história, buscando demonstrar como a construção do esquecimento, entre outros desdobramentos, relaciona-se também com a dinâmica construtiva das análises acadêmicas.

Palavras-chave: Historiografia - Governo João Goulart - Golpe de Estado de 1964

The João Goulart Government and the 1964 coup d'état: memory, history and historiography

An analysis of the various interpretative and historiography approaches on the political career of former president João Goulart, the institutional crisis of the early 1960's and the 1964 coup d'état. Special emphasis was placed on the memory/history relation, showing how the construction of oblivion, among other developments, is related to the constructive dynamics of academic analyses.

Keywords: Historigraphy - Brazilian João Goulart Government - 1964 coup d'état.

\footnotetext{
*Artigo recebido e aprovado para publicação em julho de 2009.

** Professora titular do Departamento de História da PUC/MG, professora do Departamento de História da UFMG e Pesquisadora Colaboradora Sênior da UNB.
} 
Le gouvernement João Goulart et le coup d'Etat de 1964 : mémoire, histoire et historiographie

Analyse sur les différentes approches interprétatives et historiographiques relatives à la trajectoire politique de l'ex-président João Goulart, la crise institutionnelle du début des années 1960 et le coup politique de 1964. Un accent particulier est mis sur la relation de la mémoire avec l'histoire, dans le but de démontrer comment la construction de l'oubli, entre autres développements, est liée à la dynamique constructive des analyses académiques.

Mots-clés : Historiographie - Gouvernement Brésilien João Goulart- Coup d'Etat de 1964

\section{Memória, história e construção do esquecimento}

O conhecimento e análise da trajetória humana em múltiplas temporalidades é objeto peculiar da História. O historiador, ao deslocar seu olhar crítico para o passado, procura compreender as ações dos sujeitos históricos, suas motivações e as condições nas quais foram empreendidas. Busca também entender o registro dessas ações, através da análise crítica das fontes documentais preservadas ou mal conservadas e também das razões que levaram, quando é o caso, à sua destruição ou abandono. Ao fazê-lo, muitas vezes, dialoga com manifestações da memória caracterizadas por conflitos, lembranças, esquecimentos, silêncios e comemorações. Trata-se, como afirma Ricoeur, do movimento dialético que caracteriza as relações entre esquecimento e lembrança, sempre presente na condição histórica. ${ }^{1}$

O conhecimento histórico e também a memória são campos sempre permeáveis aos interesses dos sujeitos individuais e coletivos, que atuam nas diversas conjunturas, nas quais o homem constrói o processar da História. ${ }^{2}$ São também terrenos férteis para expressão de disputas políticas, sociais e, sobretudo, de registros das práticas de exercício do poder. História e memória $\underline{\text { são altamente seletivas. A prevalência da rememoração ou do esquecimento }}$ ${ }^{1}$ Paul Ricoeur, A memória, a história, o esquecimento, Campinas, Editora UNICAMP, 2000.

${ }^{2}$ Para José Carlos Reis, "Em cada presente, o que se tem é uma visão parcial, uma articulação original entre passado e futuro. A história é visada segundo perspectivas diversas, e, com o avanço do tempo, as proposições históricas mudam. Todo historiador é marcado por seu lugar social, por sua 'data' e por sua pessoa”, in: José Carlos Reis, Tempo, História e Evasão, Campinas, Papirus, 1994. 
apresenta ressonância significativa no conteúdo da produção historiográfica, que se entrelaça à memória coletiva.

Para Delgado, ${ }^{3}$ História, tempo e memória são processos interligados, nos quais o tempo da memória ultrapassa o tempo individual e se encontra com a história das sociedades. Essa correlação explica por que alguns indivíduos se reportam a determinados contextos de forma saudosista mesmo sem os ter vivenciado e desqualificam outros sem deles terem sido contemporâneos. Tal postura, inúmeras vezes, é explicativa da valorização e exaltação de algumas conjunturas e/ou processos históricos e da desqualificação e esquecimento tácito de outros.

O presente artigo analisa textos representativos da produção historiográfica referente ao governo João Belchior Marques Goulart (1961-1964) e ao golpe de estado que o depôs. A ideia nuclear, que orienta o diálogo aqui desenvolvido com autores e textos, é de que a produção historiográfica sobre a trajetória política de João Goulart ainda é numericamente pouco expressiva. Apresenta, entretanto, não poucas vezes, interpretações discordantes, em especial quando se referem ao período do seu mandato presidencial. Além disso, alguns autores avalizam as estratégias de desqualificação no que se refere à atuação do ex-presidente e de seu governo. ${ }^{4}$

O período do nacional-desenvolvimentismo no Brasil tem sido contemplado por produção historiográfica bastante significativa, com destaque especial para a atuação dos presidentes Getulio Vargas e Juscelino Kubitschek, analisados, de forma recorrente, pela historiografia. A mesma ênfase não acontece em relação a João Goulart, que tem sido relegado a um segundo plano pela produção historiográfica e também pela memória coletiva nacional. Todavia, Jango foi um dos principais líderes trabalhistas brasileiros. Orientou, com indiscutível coerência, sua prática política por uma opção de consolidação renovada da herança varguista e pela adoção e apoio a iniciativas destinadas à ampliação da cidadania social e à defesa dos interesses econômicos nacionais.

\footnotetext{
${ }^{3}$ Lucilia de Almeida Neves Delgado, História Oral: memória, tempo e identidades, Belo Horizonte, Autêntica Editora, 2006.

${ }^{4}$ No que concerne à questão da desqualificação e esquecimento referentes a João Goulart, consideramos que as ideias apresentadas no presente artigo aproximam-se das análises desenvolvidas por Carlos Fico, no livro O grande irmão. Da operação Brother Sam aos anos de chumbo. O governo dos Estados Unidos e a ditadura militar brasileira, Rio de Janeiro, Civilização Brasileira, 2008, p. 67-74; e também por Angela de Castro Gomes em artigo intitulado "Memórias em disputa: Jango Ministro do Trabalho ou dos trabalhadores?", in: Marieta de Moraes Ferreira (org.), João Goulart: entre a memória e a história, Rio de Janeiro, Editora FGV, 2006.
} 
Seu mandato presidencial, contudo, foi marcado por forte efervescência e instabilidade política relacionadas:

- ao fato de que ao se tornar o principal depositário da tradição trabalhista de Vargas também herdou seus opositores. Além disso, as forças oposicionistas não lhe davam nenhuma trégua, pois Jango amalgamou ao trabalhismo varguista real preocupação com um reformismo social amplo e transformador da realidade.

- às condições excepcionais que predominaram durante todo o seu mandato presidencial. Sua posse aconteceu em um contexto de crise, deflagrada pela ação de seus adversários políticos. Sob a égide da crise governou por três anos. A princípio, sob a vigência de um sistema de governo parlamentarista que limitava seus poderes. Em seguida, recuperada sua plena capacidade governamental, em um sistema de governo presidencialista, em um contexto, contudo, marcado por inegável polarização política, nacional e internacional.

$\mathrm{Na}$ verdade, manifestações sociais mais autônomas, que sempre foram mal absorvidas pelo processo político brasileiro, no governo de João Goulart cresceram em número e diversidade e ganharam maior densidade e capacidade de pressão. Na esfera da sociedade civil, no campo do reformismo social, destacaram-se, por exemplo, a atuação cotidiana das ligas camponesas, do movimento estudantil e das organizações sindicais. Em uma conjuntura marcada pela guerra fria, o crescimento expressivo de manifestações organizadas por essas associações, reivindicando reformulações expressivas nas políticas públicas sociais e na relação governamental com os investidores estrangeiros, contribuiu para o adensamento de uma polarização política bastante peculiar àquele tempo de dicotomia internacional.

Como presidente, João Goulart atuou, com firmeza, no escopo da democracia política, pela efetivação de uma democracia social no Brasil. Tal orientação governamental, apesar de considerada moderada por alguns segmentos do movimento social nacionalista e reformista, trouxe real desconforto aos conservadores que com ela não concordavam. Destacaram-se entre eles: a União Democrática Nacional (UDN), setores das forças armadas, igreja católica conservadora, proprietários rurais, a maior parte do empresariado nacional e investidores internacionais. Uniram-se em forte atuação desestabilizadora de seu governo, que culminou com o golpe que o destituiu. 
Antes e depois do golpe de 1964 não foram poucas as iniciativas que provocaram e induziram à desqualificação do presidente João Goulart e de sua trajetória política. Foram desenvolvidas, com eficácia crescente, por seus opositores desde sua posse como ministro do Trabalho em 1953. Estenderamse, com vigor, à conjuntura pré-1964 e ganharam fôlego nos anos sequentes ao golpe que o depôs. A elas se somou um silêncio que urdiu um esquecimento consoante com o objetivo dos responsáveis pelo regime autoritário de legitimar suas ações.

A grande imprensa também acabou por contribuir com essa linha de ação. Por muitos anos desconsiderou a possibilidade de trazer à tona qualquer notícia referente ao presidente Goulart.

À época do regime militar a justificativa tácita para essa linha editorial, adotada por jornais, rádios e televisões brasileiras, poderia ser explicada pelo controle governamental dos meios de comunicação de massa e pela necessidade de sobrevivência em tempos de arbítrio. Única exceção a essa orientação aconteceu em 1976, quando o ex-presidente faleceu no exílio. O noticiário sobre a morte de João Goulart, censurado pelo governo federal, foi bastante acanhado e traduziu não mais que a obrigação jornalística de informar. Passado o momento do calor da notícia, um forte e recorrente silêncio continuou a predominar em relação a toda e qualquer referência ao político trabalhista, que foi deputado federal, ministro de estado, vice-presidente e presidente da República.

Mais instigante ainda é o fato de que até os dias atuais, passados mais de vinte anos de encerramento do período da ditadura, poucos órgãos de imprensa se interessem em divulgar notícias referentes ao presidente Goulart. No ano de 2006, quando se completaram trinta anos de sua morte, o noticiário foi escasso, acanhado e displicente. No ano de 2008, quando a Comissão de Anistia do Ministério da Justiça concedeu, tardiamente, pensão de viúva de presidente da República a Maria Tereza Goulart, esposa de Jango, pequenas notas esparsas e curtas deram conhecimento público a essa medida oficial. Nenhuma análise mais expressiva foi esboçada e o assunto voltou ao espaço do limbo. No primeiro decênio do século XXI, exceção exemplar à regra tem sido a revista Carta Capital, que em duas ocasiões recentes trouxe como matéria de capa chamadas referentes à morte do ex-presidente. ${ }^{5}$

\footnotetext{
5 “A Obscura Morte de Jango", Carta Capital, n 537, 18 de março de 2009; e "A viúva, Jango
} e a súbita morte", Carta Capital, n 550, 17 de junho de 2009. 
No meio acadêmico também não tem sido muito diferente. Somente nos últimos cinco anos começou a crescer, de forma mais expressiva, a produção sobre temas referentes à trajetória política do ex- presidente, seu mandato presidencial e sua postura no contexto político de sua destituição. Tal movimento, ainda que tardio e necessário, baseia-se, primordialmente, em duas explicações:

- motivação relacionada às efemérides referentes aos quarenta anos do golpe civil e militar, em 2004, e aos trinta anos da morte de João Goulart, em 2006;

- formação universitária de uma nova geração de historiadores, cientistas políticos e sociólogos, que se somaram aos poucos, mas importantes esforços de pesquisa e análise anteriormente desenvolvidos sobre a conjuntura do Governo Goulart e sobre o golpe político que o encerrou.

O presente artigo analisa textos representativos dessa nova safra de produção, além de considerar interpretações pioneiras sobre o mesmo assunto, publicadas nas décadas de 1970, 1980 e 1990. Baseia-se em dois outros textos de nossa autoria ${ }^{6}$ e dialoga com artigos de historiadores que, em anos recentes, publicaram balanços sobre a produção acadêmica referente a dois temas necessariamente imbricados: trajetória e personalidade política de Goulart e golpe de $1964 .^{7}$

Como a dimensão de um artigo não possibilita a análise do conjunto da produção histórica sobre o assunto, mesmo ciente de que omissões ocorreram, uma seleção de autores foi inevitável. Os critérios que a orientaram foram os seguintes: representatividade de orientações teóricas e metodológicas e contribuição para a ampliação da pesquisa documental e debate acadêmico.

\footnotetext{
${ }^{6}$ Lucilia de Almeida Neves Delgado, "1964: temporalidades e interpretações”, in: Daniel Reis, Marcelo Ridenti e Rodrigo Patto Sá Motta, O golpe e a ditadura militar, 40 anos depois (1964-2004), Bauru, EDUSC, 2004. Lucilia de Almeida Neves Delgado, Manuela Bezerra e Virgilio Coelho, "Um olhar sobre uma lacuna: a produção historiográfica sobre o governo João Goulart", Anais do Seminário Nacional de História da Historiografia: historiografia e modernidade, Mariana, UFOP, 2007.

${ }^{7}$ Marcelo Mattos Badaró, "O governo João Goulart: novos rumos da produção historiográfica”, Revista Brasileira de História, v. 28, n. 55, São Paulo, jan./jun. 2008. Carlos Fico, op. cit., 2008. Carlos Fico, Além do golpe: versões e controvérsias sobre 1964 e a ditadura militar, Rio de Janeiro, Record, 2004. Caio Navarro Toledo, "1964: golpismo e democracia. As falácias do revisionismo", Crítica Marxista, n. 19, 2004.
} 


\section{Historiografia e temporalidade}

Toda produção historiográfica tem como pressuposto duas dimensões inerentes ao movimento da História: tempo e espaço. As concepções sobre o tempo em sua heterogeneidade estão registradas em análises e interpretações vinculadas a diferentes teorias sobre a temporalidade e seus processos diacrônicos e sincrônicos. Há interpretações, por exemplo, que privilegiam a dimensão do tempo longo. Outras destacam os movimentos conjunturais e de impacto imediato como sendo os verdadeiramente revolucionários e transformadores. Longos ou curtos, simultâneos ou sucessivos, passados ou futuros os tempos são substratos da dinâmica histórica. Trazem em si a História enquanto realização concreta das ações humanas e também a História como conhecimento produzido. Em outras palavras, para um melhor entendimento sobre a produção do conhecimento histórico e historiográfico é fundamental considerar dois tempos específicos: o referente ao desenrolar dos acontecimentos e processos, e o relativo à produção de interpretações e narrativas sobre esses mesmos acontecimentos e processos.

Quanto ao espaço, também exerce forte influência sobre as produções históricas e historiográficas, pois as análises estão integradas à cultura de um determinado grupo, inserido em um local específico, marcado por hábitos, valores e vivências peculiares.

O processo histórico que marcou a trajetória republicana brasileira nos anos de 1961 a 1964 tem sido objeto de interpretações, ora divergentes, ora complementares. Mas, com certeza, elaboradas sob influência de teorias ou concepções hegemônicas no período em que foram produzidas e também das condições de acesso a fontes documentais e aos conteúdos nelas encontrados.

A produção historiográfica referente ao governo João Goulart e ao golpe de $1964,{ }^{8}$ apresentada no presente texto, assim está classificada:

- visão estruturalista das razões que levaram à deposição do presidente Goulart;

- ênfase no caráter preventivo do golpe político;

- caracterização conspiratória das ações que culminaram com o golpe de estado;

- visão conjuntural, com destaque para a questão da democracia;

\footnotetext{
${ }^{8}$ Cabe esclarecer que, em razão das dimensões deste artigo, não incorporamos ao balanço apresentado biografias e livros de depoimentos e de memórias.
} 
- novo ciclo produtivo: acesso a documentação inédita, registro de efemérides e registros da relação memória e história.

\section{Visões estruturalistas e funcionais}

As análises que privilegiam um enfoque estruturalista predominaram na década de 1970. Foram elaboradas por intelectuais ligados a diferentes universidades do eixo Rio/São Paulo e a alguns centros de pesquisa, como o CEBRAP e o CEDEC, criados para absorver pesquisadores afastados da docência universitária pelo regime militar.

Filiam-se à dimensão dos tempos longos e médios e relacionam a crise institucional do início da década de 1960 e a deposição do presidente João Goulart a problemas atávicos da realidade nacional, com ênfase para o subdesenvolvimento e para o atraso da industrialização do Brasil.

Entre os autores que adotam essa linha interpretativa há uma predominância de sociólogos, economistas e cientistas políticos. Os historiadores, naqueles anos, ainda muito influenciados pelas proposições cientificistas que definiam a necessidade de distanciamento temporal para realização de pesquisas históricas, não se arvoraram a interpretar os acontecimentos da recém-conclusa década de 1960.

Para efeito de apresentação das ideias que reportam à dimensão estrutural da História, selecionamos os seguintes autores: Otávio Ianni, ${ }^{9}$ Fernando Henrique Cardoso, ${ }^{10}$ Maria da Conceição Tavares ${ }^{11}$ e Francisco de Oliveira. $^{12}$

Cada um deles apresenta ideias e proposições acerca dos acontecimentos do início da década de 1960 bastante peculiares e em alguns pontos até divergentes. Esse é o caso, por exemplo, dos economistas Tavares e Oliveira. Enquanto a primeira defende a ideia que a ruptura institucional foi precedida e influenciada por uma crise generalizada de realização (baixo consumo), Oliveira afirma que só chegou a haver uma crise de realização para os produtos

9 Otávio Ianni, O colapso do populismo no Brasil, Rio de Janeiro, Civilização Brasileira, 1971.

${ }^{10}$ Fernando Henrique Cardoso, "Associated-dependent development: theoretical and practical implications", in: Alfred Stepan (Ed.), Authoritarian Brazil, New Haven, Yale University Press, 1973.

${ }^{11}$ Maria da Conceição Tavares, Da substituição de importações ao capitalismo financeiro, Rio de Janeiro, Zahar, 1975.

${ }^{12}$ Francisco Oliveira, Economia Brasileira: a crítica à razão dualista, São Paulo, CEBRAP, 1975. 
destinados ao consumo da população menos favorecida, em decorrência do processo de concentração de renda a partir do Governo Juscelino Kubitschek. Para esse autor, o desenvolvimentismo juscelinista, com sua política industrializante que favorecia a produção de bens de consumo duráveis destinados a uma camada restrita da população, contribuiu para o aprofundamento das desigualdades sociais no Brasil. Além disso, propiciou uma expressão aguda de descontentamento social no Governo Goulart que sucedeu ao quinquênio desenvolvimentista de JK.

Apesar das diferenças explicativas presentes em alguns dos enfoques acima apresentados, essas interpretações apresentam argumentação nuclear comum que aproxima os diferentes autores. Trata-se da opção pelo registro estruturalista dos processos econômico, social e político brasileiros. Segundo esses autores, na década de 1960 as atávicas contradições brasileiras acirraram o confronto político que se desdobrou na deposição do presidente Jango.

A convergência de suas ideias assim se manifesta:

- convicção de que o processo de industrialização tardia no Brasil atingiu um ponto crítico, que demandava soluções para resolução dos conflitos sociais a ele inerentes. Tais soluções se apresentaram sob a forma autoritária de regulação dos referidos conflitos;

- vinculação do golpe político às incompatibilidades entre os modelos agrário exportador e o desenvolvimentista industrializado e internacionalizado;

- convicção de que a opção por um econômico industrializante internacionalizado consolidou a dependência econômica, gerou crescente concentração da renda e propiciou eclosão de contundentes manifestações sociais reformistas e nacionalistas. Esse processo levou à ruptura do "pacto populista".

O golpe, portanto, tornou-se inevitável, pois decorreu de um agudo acirramento do conflito social, que ganhou dimensões de disputa política e ideológica. ${ }^{13}$

\section{Interpretações que enfatizam o caráter preventivo do golpe civil e militar de 1964}

\footnotetext{
${ }^{13}$ Sobre a tese da inevitabilidade do golpe, ver: Jorge Ferreira, "O governo João Goulart e o golpe civil militar de 1964", in: Jorge Ferreira e Lucilia de Almeida Neves Delgado (org.), $O$ Brasil Republicano. O tempo da experiência democrática - da democratização de 1945 ao golpe civil e militar de 1964, Rio de Janeiro, Civilização Brasileira, 2003, vol. 3.
} 
Os seguintes autores são muito representativos das análises que identificam o golpe político de 1964 como preventivo. São eles, o sociólogo Florestan Fernandes ${ }^{14}$ e os historiadores Caio Navarro de Toledo ${ }^{15}$ Lucilia de Almeida Neves Delgado ${ }^{16}$ e Jacob Gorender. ${ }^{17}$ Suas ideias convergem quanto ao entendimento de que a principal motivação do golpe que depôs o governo constitucional, empossado em 1961, foi consequente de forte descontentamento de setores conservadores da política brasileira com a crescente e autônoma organização da sociedade civil naquela conjuntura.

A destituição do presidente da República, bem como o afastamento compulsivo de seus aliados da vida pública nacional, segundo seu entendimento, objetivou evitar potenciais e profundas modificações na estrutura econômica e política do Brasil. O caráter transformador das reformas estruturais, reivindicadas pelo movimento social, não foi assimilado nem pelos setores tradicionais da sociedade brasileira, vinculados à propriedade latifundiária, nem pelos modernos representantes de um modelo capitalista industrializado e internacionalizado.

As análises desses autores mesclam horizontes da longa duração com motivações conjunturais e enfatizam que os militares e civis que depuseram João Goulart agiram impulsionados por uma perspectiva preventiva. Isso porque o projeto de reformas de base, inclusive os da reforma agrária e do controle da remessa de lucros, ensejou nos setores conservadores o temor de uma revolução social. Essa convicção e temor de que o Brasil poderia adotar um modelo distributivo ou até mesmo, de acordo com Florestan Fernandes, caminhar em direção ao socialismo levou-os a se organizarem para pôr fim ao governo Jango.

Cabe destacar que Fernandes aprofunda análise que identifica a ruptura política de 1964 como contra-revolução, que impediu a transição de

${ }^{14}$ Florestan Fernandes, O Brasil em compasso de espera, São Paulo, HUCITEC, 1981. Florestan Fernandes, "O significado da ditadura militar", in: Caio Navarro Toledo (org.), 1964: visões críticas do golpe-democracia e reformas no populismo, Campinas, Editora da UNICAMP, 1997.

${ }^{15}$ Caio Navarro Toledo, Democracia populista golpeada, op. cit., 1997. Caio Navarro Toledo, O governo Goulart e o golpe de 64, São Paulo, Brasiliense, 1984.

${ }^{16}$ Lucilia de Almeida Neves Delgado, PTB: do getulismo ao reformismo (1945-1964), São Paulo, Marco Zero, 1989. Lucilia de Almeida Neves Delgado, "Trabalhadores na crise do populismo: utopia e reformismo", in: Caio Navarro Toledo, op. cit., 1997. Lucilia de Almeida Neves Delgado, "Partidos políticos e frentes parlamentares: projetos, desafios e conflitos na democracia”, in: Jorge Ferreira e Lucilia de Almeida Neves Delgado, op. cit., 2003.

${ }_{17}$ Jacob Gorender, Combate nas Trevas. A esquerda brasileira: das ilusões perdidas à luta armada, São Paulo, Ática, 1987. 
uma democracia restrita para uma democracia ampliada. No escopo de sua argumentação acaba também por reforçar ideias que qualificam o Governo Goulart como "incompetente", "tíbio" e "débil". Portanto, incapaz tanto de evitar como de reagir à intervenção militar conservadora.

Caio Navarro de Toledo, historiador pioneiro dos estudos sobre o golpe de 1964, enfatiza que:

- a instituição de um regime autoritário no Brasil em 1964 foi decorrente de fatores conjunturais, como crise na economia, ampla mobilização política das massas populares, fortalecimento dos movimentos operário e camponês, crise do sistema partidário e inédita luta de classes decorrente da defesa de projetos dissonantes para o Brasil;

- o Governo João Goulart nasceu sob o signo do golpe e não conseguiu, apesar de seus esforços, angariar qualquer apoio das classes dominantes. Por outro lado, sofreu crescente pressão dos movimentos populares que reivindicavam maior agilidade na adoção das reformas de base. Diante do impasse, em um contexto de forte tensão, acabou por romper os limites do pacto populista e decidiu implementar as reformas reivindicadas pelos trabalhadores. A expressão maior dessa orientação política, adotada após tentativas de construção do consenso, foi o anúncio de medidas reformistas no Comício de 13 de março de 1964.

Delgado também entende que o caráter preventivo do golpe efetivou-se por uma articulação precisa dos setores conservadores. Para a autora, às vésperas de 1964, o Governo Goulart foi submetido a um tríplice confronto: com os setores conservadores nacionais aliados aos investidores internacionais; com a ala mais reformista do $\mathrm{P}$ TB, que trazia para o interior do próprio governo pressões sindicais e camponesas; com os movimentos populares e sindicais, que adquiriram grande capacidade de pressão.

Esse quadro conflituoso trouxe forte desconforto e apreensão para os setores conservadores, que passaram a acusar o Governo Goulart de incompetência, improbidade administrativa e aproximação demagógica com os movimentos populares. Era preciso, segundo seu entendimento, estagnar o crescimento dos movimentos sociais e pôr fim à experiência governamental de Jango que, por ser "demagógica", não conseguia conter as mobilizações populares e os conflitos no interior de seu próprio governo. Além disso, 
consideravam-na leniente com uma "ameaça socialista". Tais razões foram suficientes para justificar o golpe preventivo.

A análise marxista mais conhecida sobre o processo histórico do início da década de 1960 foi elaborada por Jacob Gorender em 1987. Para esclarecer a instabilidade daqueles anos, o autor recorre a explicações de base econômica estrutural, como desenvolvimento tardio do capitalismo e crise de substituição de importações. Enfatiza, contudo, o caráter preventivo da deposição de João Goulart. Adota o conceito de modernização conservadora e afirma que o núcleo burguês industrializante e os grupos representativos do capital estrangeiro, que investiam na economia brasileira, perceberam os riscos das reformas de base e optaram por aderir ao golpe preventivo e contra-revolucionário.

Gorender, como Fernandes, também identifica a conjuntura do início dos anos de 1960 como pré-revolucionária. Seu entendimento é o de que o capital industrial apostava na modernização do Brasil, mas a queria conjugada a forte controle social. Decorre desse seu entendimento sua adesão ao conceito de modernização conservadora, como aplicável ao golpe de 1964.

\section{Análises que privilegiam explicações conspiratórias do golpe}

Alguns autores, que publicaram seus livros no final da década de 1970 e ao longo da década de 1980, desenvolveram interpretações segundo as quais a ruptura da ordem política em 1964 foi decorrente de uma ação conspiratória levada adiante pela aliança dos seguintes grupos sociais e partidos políticos: setores anticomunistas das forças armadas, sendo alguns deles vinculados à Escola Superior de Guerra, parte expressiva do empresariado nacional, latifundiários e demais proprietários rurais, segmentos conservadores da igreja católica, capital internacional que tinha interesses no Brasil e entre os partidos políticos, principalmente a União Democrática Nacional (UDN).

Os conspiradores contaram com o apoio de organizações como: Agência Central de Inteligência norte-americana (CIA), Instituto de Políticas Econômicas e Sociais (IPES), Instituto Brasileiro de Ação Democrática (IBAD), Ação Democrática Parlamentar (ADP), Campanha da Mulher pela Democracia (CAMDE), Liga da Mulher Democrata (LIMDE), além de jornais da grande imprensa, que tinham uma posição antigetulista e antijanguista. Entre eles se destacavam $O$ Estado de São Paulo e O Globo.

Entre os intérpretes, que defendem a ideia básica de que o movimento de 1964 teve nas ações conspiratórias sua principal característica, selecionamos: 
Moniz Bandeira, ${ }^{18}$ René Dreiffus, ${ }^{19}$ Heloísa Starling ${ }^{20}$ e Otávio Dulci, ${ }^{21}$ que publicaram suas análises no final da década de 1970 (Bandeira), mas principalmente na década de 1980 (os demais).

Esses autores utilizam o conceito de populismo para explicar a organização hegemônica da política no Brasil pós-1945. Trabalham, de forma preferencial, com a ideia de tempo curto e enfatizam o caráter conjuntural da deposição de João Goulart.

Bandeira enfatiza que a atuação internacional foi elemento nuclear da conspiração. Segundo esse autor, no início da década de 1960, pela primeira vez na História do Brasil, os trabalhadores tiveram acesso às políticas de Estado e exerceram alguma influência nas decisões governamentais. Tal fato decorreu da habilidade de João Goulart nas relações desenvolvidas com o movimento sindical e demais organizações populares. Desde seu mandato como ministro do Trabalho e com maior ênfase quando presidente da República buscou nas demandas dos trabalhadores referências para suas políticas governamentais. Enfrentou, em razão dessa opção, forte oposição conservadora. Os mesmos setores que se opuseram à sua posse, em 1961, articularam-se para depô-lo, em 1964. Em sua mobilização conspiratória encontraram efetiva parceria na CIA e do capital internacional norte-americano.

Segundo Bandeira, a interferência norte-americana nos assuntos internos da política nacional brasileira pode ser identificada nos seguintes exemplos:

- atuação da CIA, inclusive na estratégia política de desestabilização do Governo Jango e no apoio aos políticos de oposição;

- organização da Operação Brother Sam, que previa o desembarque de marines norte-americanos no Brasil, caso houvesse uma reação do Governo Goulart e dos movimentos populares à sua deposição.

Já René Dreiffus, fundamentado em extensa e minuciosa pesquisa documental, afirma que uma mobilização popular crescente e com potencial de autonomia começou a exercer forte pressão política sobre o governo, desestabilizando a economia e trazendo risco para os investimentos internacionais. Tal fato levou à articulação de uma conspiração liderada pelo capital

${ }^{18}$ Moniz Bandeira, O Governo João Goularte as lutas sociais no Brasil, Rio de Janeiro, Civilização Brasileira, 1978.

${ }^{19}$ René Armand Dreiffus, 1964: a conquista do estado, Petrópolis, Vozes, 1981.

${ }^{20}$ Heloísa Starling, Os senhores das gerais: os novos inconfidentes e o golpe de 1964, Petrópolis, Vozes, 1986.

${ }^{21}$ Otávio Dulci, A UDN e o antipopulismo no Brasil, Belo Horizonte, Editora da UFMG/ PROED, 1986. 
multinacional, que se aliou às elites orgânicas, técnico-empresariais e aos militares brasileiros.

Organizações como o IPES e o IBAD, financiadas pelo capital internacional, atuaram no sentido de fortalecer políticos conservadores contrariados com a dinâmica política em que o populismo deixou de ser uma forma de manipulação (articulação e consentimento), transformando-se em forma de participação (expressão de demandas). Para Dreiffus a conspiração e a conquista do Estado foram decorrentes dessa mudança.

Heloísa Starling, que se filia à orientação de Dreiffus, analisa, com especial detalhamento e com base em pesquisa documental sólida, a participação de políticos e militares de Minas Gerais no movimento de deposição de Goulart. Utiliza a metáfora "novos inconfidentes" para identificar os conspiradores mineiros que se aliaram aos conspiradores nacionais e internacionais. Destaca também a atuação do IPES como tendo sido altamente coesiva junto aos políticos conservadores deste estado da federação. Para a autora o IPES fortaleceu as elites tradicionais de Minas Gerais, que se sentiam ameaçadas em uma conjuntura de forte fermentação ideológica e política.

Além disso, em Minas Gerais, as forças militares aliaram-se aos conspiradores. O alto comando da Polícia Militar foi muito atuante, e o Exército, sob o comando do General Olimpio Mourão Filho, desencadeou o primeiro deslocamento de tropas destinado a respaldar a deposição do presidente João Goulart e a enfrentar uma possível reação de seu "dispositivo militar".

Otávio Dulci, por sua vez, afirma que a atuação da UDN foi muito importante na articulação do movimento que precedeu a deposição do presidente Jango, por ele identificada como conspiração antipopulista. Considera que, na dinâmica da crise, os objetivos dos udenistas somaram-se aos de intelectuais, membros do clero e empresários, em especial os da elite empresarial do eixo Rio de Janeiro, São Paulo e Minas Gerais, que também se opunham ao populismo de João Goulart. Assinala ainda que os udenistas tiveram importante papel na agregação de expressivos setores da classe média, que apoiaram sua orientação política.

Finalmente ressalta que os políticos da UDN também fizeram oposição contundente ao presidente no parlamento, criticando a fragilidade e demagogia do seu governo e que dois importantes líderes do partido, Magalhães Pinto e Carlos Lacerda, respectivamente governadores de Minas Gerais e da 
Guanabara, tiveram importante participação nas articulações que precederam a deposição de João Goulart.

Em publicação datada de 2003, nova contribuição ao assunto ganhou grande repercussão e provocou intensos debates. Trata-se da coletânea de livros escritos pelo jornalista Élio Gaspari. Seu primeiro volume dedica parte substantiva do texto à interpretação da crise de $1964 .{ }^{22}$ Com redação clara, direta e fundamentada em vasta e inédita documentação escrita e oral, à qual teve acesso em primeira mão, Gaspari se soma aos colegas historiadores e cientistas políticos, que enfatizam a dinâmica conspiratória do golpe de 1964. O faz, todavia, em uma análise exclusivamente contextual que acentua a importância dos militares no momento do golpe e nas articulações que o antecederam.

\section{Interpretações que enfatizam uma visão conjuntural, com des- taque para a questão da democracia}

Três autores, Wanderley Guilherme dos Santos, ${ }^{23}$ Argelina Figueiredo ${ }^{24}$ e Jorge Ferreira, ${ }^{25}$ são muito representativos de uma linha interpretativa que alcançou grande repercussão na comunidade acadêmica nos últimos anos, apesar da contribuição de Santos ter sido publicada em 1986. Sua principal característica reside na sobrevalorização dos aspectos políticos da conjuntura pré-1964 e na adesão à interpretação histórica do tempo curto, quase contextual.

Em Figueiredo e Ferreira, a ênfase nos aspectos políticos da crise do início da década de 1960 ganha dimensão renovada, pois incorpora opinião de que a ausência de compromisso conjuntural, tanto dos segmentos de "esquerda" quanto dos grupos "conservadores e de direita", favoreceu o golpe de 1964.

As análises desenvolvidas por Argelina Figueiredo e Jorge Ferreira são identificadas por Toledo ${ }^{26}$ e Badaró ${ }^{27}$ como revisionistas. Concordamos que,

22 Élio Gaspari, A ditadura envergonhada, São Paulo, Companhia das Letras, 2002.

${ }^{23}$ Wanderley Guilherme Santos, Sessenta e quatro: anatomia da crise, Rio de Janeiro, Vértice, 1986.

${ }^{24}$ Argelina Cheibub Figueiredo, Democracia ou Reformas? Alternativas democráticas à crise política - 1961-1964, Rio de Janeiro, Paz e Terra, 1993.

${ }^{25}$ Jorge Ferreira, op. cit., 2003. "A estratégia do confronto: A Frente de Mobilização Popular", in: Revista Brasileira de História, São Paulo, Anpuh, vol. 24, n. 47, jan.jun. 2004.

${ }^{26}$ Caio Navarro Toledo, op. cit., 2004.

${ }^{27}$ Marcelo Badaró, op. cit., 2006. 
pelo ângulo de sobrevalorização dos conflitos conjunturais em relação aos fatores estruturais, de certa forma, podem assim ser consideradas. A mesma ênfase avaliativa, entretanto, não se adéqua à sua visão sobre a questão da democracia. Isso porque as críticas às proposições de Figueiredo e Ferreira não levam em consideração que a teoria da democracia não é unívoca e sua prática é complexa.

Análise, entre outras, sobre as diferentes formas de democracia, apresentada por Daniel Aarão Reis em texto datado de $1986,{ }^{28}$ muito contribui para a consideração de uma visão mais complexa da questão democrática. Segundo seu entendimento a democracia apresenta três dimensões: social, relacionada à distribuição da renda, direitos e propriedade; nacional, relativa à questão da dependência econômica e seus desdobramentos, e política, referente à real participação da sociedade civil na dinâmica política de seu país e comunidade. Dialogando com Reis, nosso entendimento é o de que a democracia, em sua forma ideal, é uma rede complexa de dimensões interconectadas que contempla deveres e direitos da cidadania, com especial destaque para os direitos sociais, econômicos, políticos.

Ora, as análises apresentadas por Figueiredo e Ferreira se referem à dimensão política da democracia liberal clássica, que é prioritariamente representativa e inclui em sua dinâmica, entre outras variáveis: eleições rotineiras, possibilidade de alternância no poder, liberdade de organização e expressão, e condições consolidadas e respeitadas de governabilidade.

$\mathrm{Na}$ realidade, os dois autores não deixam de ter razão quando afirmam que às vésperas de 1964 as condições de governabilidade foram desestabilizadas pela atuação cotidiana de sujeitos históricos em conflito. Além disso, em nossa opinião, cabe considerar que naqueles anos também estava em curso forte disputa referente à priorização de diferentes opções de democracia. Os movimentos sociais reformistas priorizavam a defesa da democracia econômica e social, com certeza escassa e necessária no Brasil. Já os setores conservadores arvoravam-se como defensores da democracia política representativa que eles mesmos acabaram por ferir de morte, quando do golpe de 1964.

A breve reflexão acima apresentada sobre a questão democrática orienta a seguir apresentação um pouco mais detalhada das interpretações de Figueiredo e Ferreira.

${ }^{28}$ Daniel Reis, “As organizações comunistas e a democracia”, in: Marco Aurélio Garcia (org.), As esquerdas e a democracia, Rio de Janeiro, Paz e Terra/CEDEC, 1986. 
Argelina Figueiredo, ao se referir à conjuntura que precedeu ao golpe de 1964, enfatiza o argumento de que as possibilidades de ampliação e consolidação de apoio às reformas foram prejudicadas por escolhas e ações específicas que reduziram as oportunidades de sua implementação sob regras democráticas. Considera, também, que o conflito entre os defensores de opções políticas opostas radicalizou-se, desestabilizou as condições de governabilidade, acirrou o consenso negativo e solapou as possibilidades de manutenção da ordem democrática.

Em seu entendimento, portanto, a crise teve como característica forte conflito entre os opositores e os defensores das reformas de base, que se descuidaram do compromisso com a democracia política institucional. Mas os textos de Figueiredo, bem como os de Ferreira, não indicam que esses dois autores entendem que no período que antecedeu 31 de março os setores de esquerda estivessem urdindo um golpe político.

Ferreira, que por sua vez compartilha a argumentação de Figueiredo, afirma que:

- na historiografia sobre 1964 predominam paradigmas tradicionais, estruturalistas ou individualistas (personalização da culpa do golpe);

- o golpe não pode ser explicado apenas por fatores externos - conspiração internacional; Jango apresentou plano de governo com a estratégia de aprovar as reformas de base (Plano Trienal). Essa estratégia, contudo, falhou por recusa das partes envolvidas no processo em negociar;

- a democracia não era prioritária nem na agenda da direita nem na da esquerda.

Finalmente, Wanderley Guilherme dos Santos, em detalhada elaboração analítica, afirma também ser necessário aplicar variáveis políticas aos esquemas explicativos estruturalistas de base econômica sobre o golpe de 1964. Sua linha interpretativa busca na política as principais explicações sobre a crise que culminou com a deposição de João Goulart. Ao fazê-lo, enfatiza que houve uma crise de governabilidade conjuntural, assim caracterizada: paralisia decisória, que contaminou o parlamento e o poder executivo; fragmentação de recursos de poder; radicalização ideológica; inconstância das coalizões formadas no Congresso Nacional; instabilidade governamental (rotatividade na direção de ministérios e agências estatais) e dispersão partidária. 
Em suma, para Santos, Figueiredo e Ferreira, não foram dimensões estruturais, mas sim a radicalização política e a recusa à construção de um consenso em prol da governabilidade, os maiores responsáveis pelo rompimento da ordem constitucional em 1964.

\section{Novo ciclo produtivo: acesso a documentação inédita, registro de efemérides e da relação memória e história}

No início do presente século, historiadores de uma nova geração trouxeram alento especial à produção historiográfica sobre os últimos anos do ciclo histórico encerrado em 1964. Seus trabalhos, algumas vezes em voo solo e em outras em parceria com colegas veteranos, têm contribuído para minorar o esquecimento que, durante muitos anos, predominou sobre João Goulart e seu governo. Também lançam novas luzes sobre a dinâmica do golpe que o depôs. Ao dialogarem com fontes inéditas e diversificadas adensaram, de forma significativa, o estado da arte sobre o golpe de 1964 e o regime militar.

Merece destaque especial o relevante trabalho desenvolvido por Carlos Fico. ${ }^{29}$ Suas minuciosas pesquisas levaram-no a discordar das teses conspiratórias de médio prazo sobre a deposição de João Goulart e a insistir que o movimento golpista propriamente dito foi conduzido por lideranças importantes das forças armadas, no calor da conjuntura, sem maior planejamento anterior.

Fico diferencia, de forma que consideramos muito sutil, conspiração de desestabilização. Suas análises enfatizam que não houve atuação de forças conspiratórias para depor Goulart, mas sim uma desestabilização de seu governo. As ações militares foram precipitadas pela iniciativa do General Olimpio Mourão Filho, comandante da IV Região Militar, sediada em Juiz de Fora, e em seguida apoiadas pelos opositores do presidente deposto.

Sua argumentação, que também atenta para as relações conflituosas entre memória e História, identifica que partidos políticos, organizações de oposicionistas da sociedade civil e setores da igreja católica, que se opunham a João Goulart, atuaram em prol da desqualificação e desestabilização de seu governo. Mas que na linha de frente da deposição do ex-presidente e do governo que a sucedeu estavam os militares.

${ }^{29}$ Carlos Fico, op. cit., 2004. Carlos Fico, O grande irmão. Da Operação Brother Sam aos anos de chumbo. O governo dos Estados Unidos e a ditadura militar brasileira, Rio de Janeiro, Civilização Brasileira, 2008. 
Fico, todavia, não desconhece que no cenário da guerra fria o governo dos EUA estava muito preocupado com os desdobramentos da política no Brasil. Em pesquisa realizada no Arquivo Nacional norte-americano teve acesso a documentos, que contribuem para melhor compreensão da Operação Brother Sam e seus impactos nos acontecimentos de 1964.

Aporte instigante e bastante original ao debate acadêmico sobre os anos João Goulart é encontrado em livro oriundo da produção de Rodrigo Pato Sá Motta. ${ }^{30}$ As principais fontes da pesquisa por ele realizada são caricaturas de Jango, quando presidente da República. Buscadas em diferentes periódicos, levaram o autor a apresentar, entre outras, as seguintes constatações: que no período de instabilidade do início da década de 1960, caricaturistas, de forma geral, contribuíram para disseminar uma imagem negativa do presidente Jango, e que as críticas expressas nos traços desses artistas também se somaram ao caldo de manifestações que levaram ao enfraquecimento de seu governo.

Quanto às efemérides outros importantes livros, além dos de $\mathrm{Fico}^{31} \mathrm{e}$ Motta, ${ }^{32}$ foram lançados nessas ocasiões. Organizados, na sua maioria, como coletâneas, no ano de 2004, aos quarenta anos do golpe, e no ano de 2006, aos trinta anos da morte de João Goulart, acrescentaram relevantes análises sobre a crise institucional e a deposição de Goulart. Também tornaram públicas novas informações sobre um tema pouco visitado: a trajetória política de Jango. ${ }^{33}$

O escopo deste artigo não absorve a possibilidade de comentá-los de forma mais detida, posto que escritos por muitos autores, mas algumas inferências indicam a dimensão de sua relevância:

- no conjunto, quatro deles, incluindo o de autoria de Motta, trazem o nome João Goulart no seu título. Mais do que isso, o livro publicado por Jorge Ferreira e Angela de Castro Gomes é inteiramente dedicado a analisar sua carreira e seu perfil político. Essas escolhas talvez pos-

${ }^{30}$ Rodrigo Patto Sá Motta, Jango e o golpe de 1964 na caricatura, Rio de Janeiro, Jorge Zahar Editor, 2006.

${ }^{31}$ Carlos Fico, op. cit., 2004.

32 Rodrigo Motta, op. cit., 2006.

${ }_{33}$ Trata-se dos seguintes livros: Daniel Reis; Marcelo Ridente e Rodrigo Motta. O golpe e a ditadura militar, 40 anos depois, Bauru, EDUSC, 2004. Oswaldo Munteal; Jacqueline Ventapane e Adriano Freixo (org.), O Brasil de João Goulart: um projeto de nação, Rio de Janeiro, Contraponto/Ed. PUC-Rio, 2006. Marieta Ferreira (org.), João Goulart. Entre a memória e a história, Rio de Janeiro, Editora FGV, 2006. Angela de Castro Gomes e Jorge Ferreira, Jango, as múltiplas faces, Rio de Janeiro, Editora FGV, 2006. Seminário 40 Anos do Golpe de 1964, 1964-2004: quarenta anos do golpe - ditadura militar e resistência no Brasil, Rio de Janeiro, Sete Letras, 2004. 
sam ser indicativas de que o homem público, João Belchior Marques Goulart, começa a ser reconhecido como importante sujeito histórico da trajetória republicana brasileira;

- sua elaboração contou com textos de gerações diferentes de historiadores, o que propiciou diálogo de temporalidades e de opções teóricas e metodológicas;

- alguns deles, com realce especial para os assinados por Fico, Ferreira, Gomes, Motta, Munteal, Ventapane e Freixo, apresentam pesquisa original de fontes, que traz novas informações para construção do conhecimento histórico e para um melhor balizamento da produção anterior;

- a discussão sobre a relação entre memória, história e esquecimento, com foco na pessoa de João Goulart, é trabalhada com acuidade por Angela de Castro Gomes, Marieta Ferreira e Carlos Fico. A análise dos três autores sobre Jango coincide com a apresentada no início deste artigo. Ou seja, pouca atenção tem sido dada ao ex-presidente cuja trajetória tem sido alvo de dois movimentos indutivos: de construção do esquecimento e de predomínio do silêncio. Ambos estão inseridos no campo de memórias em conflito.

\section{Considerações finais}

A efervescência do início da década de 1964 e os acontecimentos, conflitos e projetos que a caracterizam tiveram como desfecho o golpe de estado de 1964, marco inaugural de uma conjuntura política, marcada por crescente autoritarismo.

Não foi a primeira vez, na trajetória republicana brasileira, que uma experiência democrática foi interrompida. Triste sina a da realidade política do Brasil! Usualmente não considera normais as disputas e divergências peculiares à democracia política e muito menos absorve a efetiva participação de organizações populares no cotidiano das relações políticas. Assim aconteceu em 1964.

$\mathrm{Na}$ verdade, o estigma autoritário que tem marcado como tatuagem a tradição histórica brasileira se fez presente naquele ano e nos que o sucederam. Como consequência, o dilema referente à dificuldade de consolidação de experiências democráticas no Brasil continuou a permear o cotidiano da população brasileira nos anos que sucederam ao golpe de estado. 
Analisar os fatores que engendram rupturas de ordens democráticas é tarefa complexa, supõe identificação e compreensão da multiplicidade de variáveis presentes nas conjunturas que precedem essas rupturas e supõe também compreensão da realidade da longa duração que nelas se atualiza. Somente nas relações entre variáveis estruturais e conjunturais encontram-se explicações consistentes para processos e acontecimentos históricos.

Nesse sentido, o diálogo de contribuições diversificadas baseadas em sólidas pesquisas documentais e em referenciais teóricos adequados poderá ampliar o ainda acanhado conhecimento sobre a dinâmica daquele tempo de muita História. Passados mais de quarenta anos da tomada do poder pelos militares, os indícios são de que a história contemporânea do Brasil vem atraindo novos pesquisadores que dialogam com o passado fundamentando-se em vasta documentação, grande parte dela ainda virgem.

Finalmente cabe registrar que este balanço não deve ser encerrado sem o registro de nossa convicção de que os responsáveis pela deposição de João Goulart foram militares, respaldados por apoio internacional e em parceria com partidos políticos, segmentos e organizações da sociedade civil que se opunham à opção política do presidente e de seus aliados históricos.

Foram os grupos conservadores, históricos opositores do trabalhismo e de João Goulart, os responsáveis pela interrupção da experiência democrática brasileira em 1964. Foram eles também que, à frente do governo federal, reproduziram por vinte anos uma prática discricionária, autoritária, arbitrária e excludente. Inauguraram e reproduziram o tempo da ditadura no Brasil pós-1964. 